\title{
KARAKTER TINGGI TANAMAN, UMUR PANEN, JUMLAH ANAKAN, DAN BERAT PANEN PADA 12 GENOTIPE PADI LOKAL KABUPATEN KUANTAN SINGINGI
}

\section{Plant height character, harvest age, number of children, and harvest weight in 12 local rice genotypes of Singingi quantity}

\author{
Dwi Afdila ${ }^{1}$, Chairil Ezward*2, A. Haitami ${ }^{2}$ \\ ${ }^{1}$ Agrotechnology Study Program Student \\ ${ }^{2}$ Lecturer at the Agrotechnology Study Program \\ Faculty of Agriculture, Kuantan Singingi Islamic University \\ *Corresponding Author, email : ezwardchairil@yahoo.com \\ HP/WA. 0852.6238.0410
}

\begin{abstract}
Abstrak
Penelitian ini bertujuan untuk mengetahui perbedaan 12 genotipe padi lokal (Oryza sativa L) Kabupaten Kuantan Singingi terhadap karakter tinggi tanaman, umur panen, jumlah anakan, dan berat panen. Penelitian ini telah dilaksanakan di desa Petapahan Kecamatan gunung toar Kabupaten Kuantan Singingi. Rancangan yang digunakan adalah Rancangan Acak Kelompok Non Faktorial yang terdiri dari 12 genotipe padi lokal yaitu : padi singgam kuriak (PL01), pulut solok (PL02), pulut kari (PL03), pulut benai (PL04), pulut kuning (PL05), padi adam (PL06), padi putih (PL07), lupo ka laki (PL08), padi kuning (PL09), Padi Gondok (PL10), saronda kuning (PL11), katiok putih (PL12). Hasil penelitian ini menunjukkan berpengaruh nyata terhadap tinggi tanaman dan umur panen. Perlakuan tinggi tanaman $(\mathrm{cm})$ terbaik adalah pada PL09 (Padi Kuning) yaitu 140,94 cm dan perlakuan terbaik umur panen (HST) adalah PL11 (Saronda Kuning) yaitu 104 HST sedangkan jumlah anakan dan berat panen tidak memberikan pengaruh yang nyata.
\end{abstract}

Kata kunci : Berat panen, genotipe padi lokal,jumlah anakan, tinggi tanaman, dan umur panen

\begin{abstract}
This research aims to determine the differences in 12 local rice genotypes (Oryza sativa L) in Kuantan Singingi Regency on the characteristics of plant height, harvest age, number of tillers, and harvest weight. This research was conducted in Petapahan village, Gunung toar district of Kuantan Singingi. The design used was a non-factorial randomized block design consisting of 12 local rice genotypes, namely : padi singgam kuriak (PL01), pulut solok (PL02), pulut kari (PL03), pulut benai (PL04), pulut kuning (PL05), padi adam (PL06), padi putih (PL07), lupo ka laki (PL08), padi kuning (PL09), Padi Gondok (PL10), saronda kuning (PL11), katiok putih (PL12). The results of this study showed a significant effect on plant height and harvest age. The best treatment for plant height was PL09 (Padi Kuning) which was $140.94 \mathrm{~cm}$ and the best treatment for harvesting age was PL11 (Saronda Kuning) which was 104 days after planting, while the number of tillers and harvest weight did not have a significant effect.
\end{abstract}

Key words : Harvest weight, local rice genotype, number of tillers, plant height, and age of harvest 


\section{PENDAHULUAN}

Padi (Oryza sativa L.) merupakan tanaman pangan yang sangat penting di dunia setelah gandum dan jagung (Purnamaningsi, 2006). Hampir separuh penduduk dunia terutama Asia mengggantungkan hidupnya dari tanaman padi, begitu pentingnya tanaman padi sehingga kegagalan panen dapat mengakibatkan gejolak sosial yang luas.

Riau sebagai salah satu provinsi yang letaknya sangat strategis dari sisi ekonomi, terdapat banyak beras-beras yang berasal dari luar provinsi Riau sendiri. Kebutuhan Beras masih didatangkan dari Provinsi Sumatera Utara, Sumatera Selatan, Sumatera Barat. Sampai saat ini Riau belum mampu untuk memenuhi kebutuhan pangan khususnya padi, walaupun ada (9) wilayah yang merupakan potensi sebagai basis peningkatan produksi padi seperti Kabupaten Indragiri Hilir, Indragiri Hulu, Pelelawan, Siak, Bengkalis, Rokan Hulu, Rokan Hilir, Kampar, dan Kuantan Singingi (Nurhayati, Jamil, Zona, Jarkoni, Alim, Elfiani, dan Empersi, 2012) dalam (Ezward, Dadang dan Haris, 2019).

Kabupaten Kuantan Singingi (Kuansing) merupakan salah satu Kabupaten yang menghasilkan beras di Propinsi Riau. Kuansing merupakan salah satu daerah yang potensial untuk budidaya tanaman padi (Ezward, et al (2017).

Kabupaten Kuantan Singingi mempunyai potensi pertanian yang sangat besar untuk dikembangkan. Daya dukung dan lahan yang besar, lebih dari setengah jumlah penduduk bekerja pada sektor pertanian dengan keterampilan dasar yang dimiliki, pasar yang tersedia dengan infrastruktur yang sedang digalakkan, merupakan modal dasar untuk pengembangan padi. Namun terkadang masih terdapat masalah yang sangat perlu untuk diperhatikan yaitu pelestarian padi lokal.

Pembudidayaan tanaman padi dapat menggunakan varietas unggul atau genotipe padi lokal. Keuntungan dalam penggunaan genotipe padi lokal adalah lebih toleran dengan cekaman lingkungan karena adaptasinya tidak luas (spesifik lokasi), kemudian sesuai selera konsumen setempat, hasil lebih stabil.

Hal ini dapat terjadi karena kondisi cuaca di Kabupaten Kuantan Singingi umumnya sedikit ekstrim. Apabila hujan dapat menimbulkan banjir di sawah dan akan menyebabkan penanaman akan diulang. Apabila kemarau, maka panas dapat menimbulkan terlambatnya pemindahan bibit kelahan sawah. Kedua hal ini berpengaruh terhadap hasil padi dan penghasilan petani. Contoh beberapa varietas yang diakui oleh masyarakat seperti padi singgam putih, padi kuning dan padi merah. Menurut hasil penelitian Indrawanis, Chairil dan Mashadi (2014), berat kering padi singgam putih 5,44 ton/ha, padi kuning 5,60 ton/ha.

Oleh karena itu penelitian bertujuan untuk mengetahui perbedaan 12 genotipe padi lokal (Oryza sativa.L) Kabupaten Kuantan Singingi terhadap tinggi tanaman, umur panen, jumlah anakan, dan berat panen.

\section{METODOLOGI PENELITIAN}

Penelitian ini telah dilaksanakan di desa Petapahan Kecamatan gunung toar Kabupaten Kuantan Singingi. Penelitian ini berlangsung selama 5 bulan dari bulan November 2019 sampai Maret 2020. Bahan yang digunakan dalam penelitian ini adalah genotipe padi lokal Kabupaten Kuantan Singingi, yaitu padi singgam kuriak (PL01), pulut solok (PL02), pulut kari (PL03), pulut benai (PL04), pulut kuning (PL05), padi adam (PL06), padi putih (PL07), lupo ka laki (PL08), padi kuning (PL09), Padi Gondok (PL10), saronda kuning (PL11), katiok putih (PL12). Rancangan yang digunakan dalam penelitian ini adalah Rancangan Acak Kelompok Non Faktorial yang terdiri dari 12 genotipe padi lokal, dimana masing-masing perlakuan terdiri dari 3 ulangan.

Data hasil penelitian yang diperoleh dari lapangan di analisis secara statistik sesuai dengan Rancangan Acak Kelompok 
Rak Non Faktorial dengan rumus sebagai berikut :

\section{$\mathbf{Y i j k}=\boldsymbol{\mu}+\mathbf{k}+\mathbf{A} \mathbf{i}+\boldsymbol{\varepsilon i j}$}

Pelaksanaan penelitian meliputi :pembibitan adapun tahapan-tahapan dalam persiapan bibit adalah sebagai berikut : Seleksi benih, perendaman benih, persemaian benih (Purwasasmita, 2002). Selanjutnya pengolahan lahan, pembuatan plot, pemasangan label, pemberian pupuk kotoran ayam, penanaman bibit, dan pemberian pupukan organik.

Tabel 1. Rerata tinggi tanaman perlakuan 12 genotipe padi lokal

\begin{tabular}{ll}
\hline Genotipe (P) & Rerata $(\mathrm{CM})$ \\
\hline PL01 : Singgam Kuriak & $121,80 \mathrm{~cd}$ \\
PL02 : Pulut Solok & $111.33 \mathrm{ef}$ \\
PL03 : Pulut Kari & $129,54 \mathrm{ab}$ \\
PL04 : Pulut Benai & $106,23 \mathrm{f}$ \\
PL05 : Pulut Kuning & $122,80 \mathrm{bc}$ \\
PL06 : Padi Adam & $133,28 \mathrm{a}$ \\
PL07 : Padi Putiah & $132,04 \mathrm{a}$ \\
PL08 : Lupo Ka Laki & $135,66 \mathrm{a}$ \\
PL09 : Padi Kuning & $140,94 \mathrm{a}$ \\
PL10 : Gondok/Pelita & $120,61 \mathrm{~d}$ \\
PL11 : Saronda Kuning & $136,57 \mathrm{a}$ \\
PL12 : Katiok Putiah & $119,37 \mathrm{de}$ \\
\hline KK=3,75\% & $\mathrm{BNJ}=14,18$ \\
\hline
\end{tabular}

Keterangan : Angka-angka pada kolom dan baris yang diikuti huruf kecil yang sama adalah tidak berbeda nyata menurut uji lanjut BNJ dengan taraf 5\%.

Berdasarkan hasil Uji Lanjut BNJ dengan taraf $5 \%$ dapt dilihat bahwa perlakuan genotipe terhadap tinggi tanaman padi lokal yang memiliki parameter tertinggi yaitu pada genotipe PL09 (Padi kuning) dengan tinggi tanaman 140,94 cm. Perlakuan genotipe ini tidak berbeda nyata dengan perlakuan genotipe PL03 (Pulut Kari), PL06 (Padi Adam), PL07 (Padi Putiah), PL08 (Lupo Ka Laki), PL09 (Padi Kuning) PL11 (Saronda Kuning). Tetapi berbeda nyata dengan perlakuan genotipe PL01 (Singgam Kuriak), PL02 (Pulut Solok), PL04 (Pulut Benai) dan PL05 (Pulut Kuning) PL10 (Gondok/Pelita) dan PL12 (Katiok Putiah). Pada genotipe tanaman padi PL09 (Padi Kuning) merupakan tanaman tertinggi. Hal ini dikarenakan setiap genotipe memiliki sifat genetik yang

\section{HASIL DAN PEMBAHASAN Tinggi Tanaman}

Berdasarkan hasil analisis sidik ragam menunjukkan bahwa genotipe berpengaruh nyata terhadap tinggi tanaman. Rata-rata tinggi tanaman padi di uji dengan $\mathrm{BNJ}$ pada taraf 5\% dapat dilihat pada tabel 1 . berbeda dan kemampuan daya adaptasi terhadap lingkungan juga berbeda pada setiap genotipe.

Tinggi tanaman adalah faktor genetik dari tanaman itu sendiri dan variasi tanaman merupakan faktor lingkungannya. Menurut Wahyuni (2008), penggunaan sumber benih dari genotipe yang berbeda akan memberikan potensi yang berbeda dan perbedaan ini akan menimbulkan keragaman penampilan. Beragamnya tinggi tanaman padi diduga karena lebih dominannya perbedaan kultivar tersebut secara genetik.

Menurut Sitompul dan Guritno (1995), yang menyatakan bahwa perbedaan susunan genetik merupakan salah satu penyebab keragaman penampilan tanaman. Program genetik yang diekspresikan pada 
berbagai sifat tanaman yang mencakup bentuk dan fungsi tanaman yang menghasilkan keragaman. Hal tersebut sejalan dengan hasil penelitian dari Anhar et al (2016), yang menyatakan bahwa jumlah anakan dan tinggi tanaman yang berbeda karena setiap varietas memiliki sifat gen yang berbeda-beda.

Perbedaan tinggi tanaman dapat dikarenakan faktor genetik suatu genotipe. Hal tersebut sejalan dengan pendapat Nazirah dan Damanik (2015), yang menyatakan bahwa perbedaan susunan genetik merupakan salah satu faktor yang menyebabkan penampilan tanaman beragam dalam hal ini adalah tinggi tanaman. Menurut Syahri dan Somantri (2013), tinggi tanaman pada tanaman padi dapat digunakan sebagai salah satu parameter pertumbuhan tetapi pertumbuhan tanaman yang tinggi belum menjamin hasil yang diperoleh lebih besar.

Genotipe yang paling rendah yaitu terdapat pada genotipe PL04 (Pulut Benai) yaitu 106,23 cm. Hal ini diakibatkan sifat dan ciri genotipe padi pulut benai tidak beradaptasi baik sehingga gen dan ciri genotipe tidak berpengaruh tetapi yang lebih berpengaruh pada tinggi tanaman oleh faktor iklim dan lingkungan. Hal ini juga dikatakan oleh Martono (2009), karakter yang rendah sampai sedang menandakan bahwa faktor lingkungan lebih berpengaruh dari faktor genetik.

Data hasil pengamatan tinggi tanaman padi pada tabel 1 sebagai acauan untuk melihat laju pertumbuhan dari 12 Genotipe padi lokal yang memberikan pengaruh terhadap tinggi tanaman, hal ini dapat dilihat pada gambar 1 .

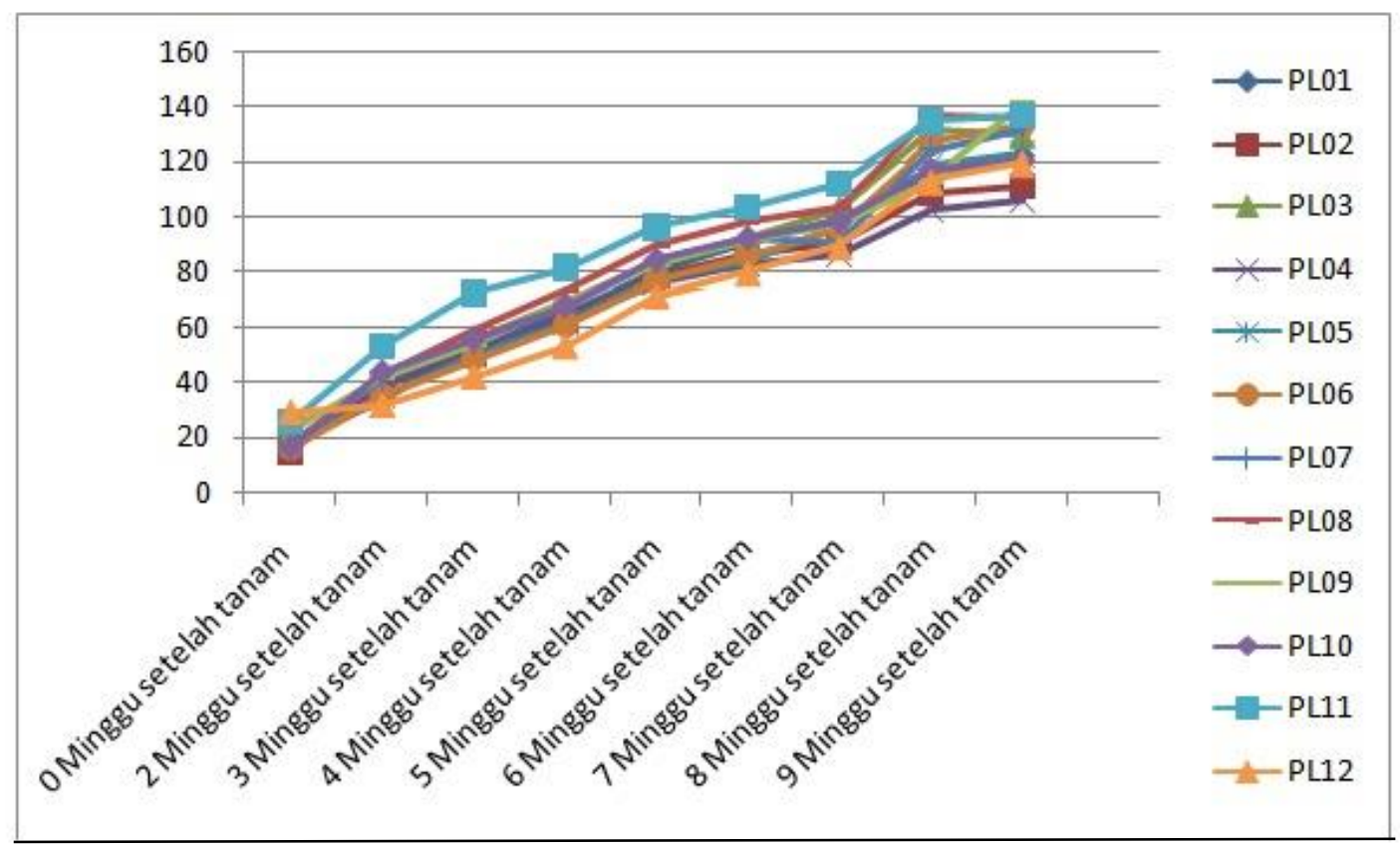

\section{Gambar 1. Histogram laju pertumbuhan tinggi tanaman terhadap 12 varietas padi lokal}

Gambar 1. Histogram laju pertumbuhan tinggi tanaman terhadap 12 varietas padi lokal

Berdasarkan gambar 1 dapat dilihat laju pertumbuhan tinggi tanaman terhadap berbagai genotipe padi lokal dari awal tanam hingga minggu ke 9 yaitu sampai munculnya bunga dan malai. Dilihat dari gambar diatas laju pertumbuhan genotipe PL09 yang pada awal tanam yaitu pemindahan bibit dari media semai kelahan penelitian dengan tinggi tanaman $15,5 \mathrm{~cm}$ dan 1 minggu setelah tanam dengan tinggi 
tanaman 42,06 $\mathrm{cm}$ dan minggu selanjutnya 53,69 $\mathrm{cm}$ hingga sampai minggu ke 9 dengan tinggi tanaman 140,94 cm. Dapat dilihat laju partumbuhan tinggi tanaman padi yang disebabkan faktor genetik masing-masing genotipe.

\section{Umur Panen}

Berdasarkan hasil analisis sidik ragam menunjukkan bahwa genotipe berpengaruh nyata terhadap parameter umur panen. Rata-rata umur panen tanaman padi di uji dengan BNJ pada taraf 5\% dapat dilihat pada tabel 2 .
Data hasil pengamatan terhadap parameter umur panen setelah dilakukan sidik ragam pada tabel 2 menunjukkan bahwa perlakuan genotipe memberikan pengaruh yang nyata terhadap parameter umur panen. Pada genotipe yang memiliki umur panen paling cepat terdapat pada genotipe PL11 (Saronda Kuning) yaitu 104 hari, juga tidak berbeda nyata dengan genotipe PL01 (Singgam Kuriak), PL08 (Lupo ka Laki), PL10 (Gondok/Pelita), PL06 (Padi Adam), PL04 (Pulut Benai), dan PL07 (Padi Putiah) tetapi berbeda nyata dengan genotipe PL02 (Pulut Solok), PL03 (Pulut Kari), PL05 (Pulut Kuning), PL09 (Padi Kuning), dan PL12 (Katiok Putiah).

Tabel 2. Rerata umur panen perlakuan 12 genotipe padi lokal

\begin{tabular}{ll}
\hline Genotipe (P) & Rerata (Hari) \\
\hline PL01 : Singgam Kuriak & $120 a$ \\
PL02 : Pulut Solok & $126 \mathrm{~cd}$ \\
PL03 : Pulut Kari & $133 \mathrm{~d}$ \\
PL04 : Pulut Benai & $120 a$ \\
PL05 : Pulut Kuning & $122 \mathrm{~b}$ \\
PL06 : Padi Adam & $104 a$ \\
PL07 : Padi Putiah & $120 a$ \\
PL08 : Lupo Ka Laki & $104 a$ \\
PL09 : Padi Kuning & $122 b$ \\
PL10 : Gondok/Pelita & $121,3 a b$ \\
PL11 : Saronda Kuning & $104 a$ \\
PL12 : Katiok Putiah & $122 b$ \\
\hline KK=0,28\% & BNJ=0,57 \\
\hline
\end{tabular}

Keterangan:Angka-angka pada kolom dan baris yang diikuti huruf kecil yang sama adalah tidak berbeda nyata menurut uji lanjut BNJ dengan taraf $5 \%$.

Genotipe yang umur panen cepat pada PL11 yaitu 104 hari sementara genotipe yang memiliki umur panen yang paling lama adalah PL03 (Pulut Kari) yaitu 133 hari. Umur tanaman berhubungan dengan faktor genetis tanaman, itulah sebabnya mengapa tiap genotipe yang diuji memiliki umur tanaman yang berbeda. Menurut Martodireso dan Sutaryo (2001), ciri-ciri padi yang siap dipanen adalah bulirbulir padi dan daun bendera sudah menguning, tangkai merunduk karena sarat menanggung bulir-bulir padi atau gabah yang bertambah berat, bulir padi bila ditekan terasa keras dan berisi dan jika dikupas tidak berwarna kehijauan atau putih agak lembek seperti kapur.

Tanaman akan memperlihatkan matang panen jika total energi yang diadopsi sudah mencapai batas taraf tertentu dan batas taraf tertentu berbedabeda pada masing-masing tanaman umumnya disebabkan oleh faktor genetis (Masdar et al., 2006). Umur tanaman 
dipengaruhi oleh kecepatan tanaman berbunga. Umur $50 \%$ berbunga berkorelasi positif dengan umur tanaman atau masa panen, artinya galur/varietas yang mempunyai umur $50 \%$ berbunga lebih pendek, maka umur masak galur/varietas tersebut juga lebih pendek, atau biasa disebut dengan berumur genjah.

\section{Jumlah Anakan (Batang)}

Berdasarkan hasil analisis sidik ragam menunjukkan bahwa setiap genotipe tidak berpengaruh nyata terhadap parameter jumlah anakan. Rata-rata jumlah anakan tanaman padi di uji dengan BNJ pada taraf $5 \%$ dapat dilihat pada tabel 3 .
Berdasarkan tabel 3 menunjukkan bahwa perlakuan genotipe tanaman padi memberikan pengaruh yang nyata terhadap parameter jumlah anakan tanaman padi. Genotipe PL11 (Saronda Kuning) memiliki rerata jumlah anakan paling banyak yaitu 11,77 batang perlakuan ini tidak berbedanya nyata dengan genotipe PL03 (Pulut Kari) PL06 (Padi Adam) dan PL04 (Pulut Benai) tetapi berbeda nyata dengan genotipe PL01 (Singgam Kuriak), PL08 (Lupo ka Laki), PL05 (Pulut Kuning), PL02 (Pulut Solok), PL12 (Katiok Putiah), PL10 (Gondok/Pelita), PL09 (Padi Kuning) dan PL07 (Padi Putiah).

Tabel 3. Rerata jumlah anakan perlakuan 12 genotipe padi lokal

\begin{tabular}{ll}
\hline Genotipe (P) & Rerata (Batang) \\
\hline PL01 : Singgam Kuriak & $7,59 \mathrm{~cd}$ \\
PL02 : Pulut Solok & $8,37 \mathrm{~cd}$ \\
PL03 : Pulut Kari & $10,18 \mathrm{a} b$ \\
PL04 : Pulut Benai & $10.47 \mathrm{a} b$ \\
PL05 : Pulut Kuning & $6,58 \mathrm{~d}$ \\
PL06 : Padi Adam & $9,93 \mathrm{ab}$ \\
PL07 : Padi Putiah & $9,18 \mathrm{bc}$ \\
PL08 : Lupo Ka Laki & $9,04 \mathrm{c}$ \\
PL09 : Padi Kuning & $7,94 \mathrm{~cd}$ \\
PL10 : Gondok/Pelita & $8,29 \mathrm{~cd}$ \\
PL11 : Saronda Kuning & $11,77 \mathrm{a}$ \\
PL12 : Katiok Putiah & $7,20 \mathrm{~cd}$ \\
\hline KK=14,23\% & $\mathrm{BNJ}=2,18$ \\
\hline
\end{tabular}

Keterangan : Angka-angka pada kolom dan baris yang diikuti huruf kecil yang sama adalah tidak berbeda nyata menurut uji lanjut BNJ dengan taraf $5 \%$.

Genotipe yang memberikan hasil terbanyak pada parameter jumlah anakan 11,77 batang anakan produktif, sementara genotipe yang memiliki jumlah anakan produktif paling sedikit adalah PL05 (Pulut Kuning) yaitu 6,58 batang anakan produktif. Jumlah anakan produktif berpengaruh langsung terhadap jumlah malai yang dihasilkan, makin banyak anakan produktif makin tinggi jumlah gabah yang akandiperoleh (Fadjrin et $a l, 2012)$. Menurut Sudirman dan Iwan (2001) dalam (Husna dan Andrian, 2010) menyatakan bahwa anakan produktif merupakan anakan yang berkembang lebih lanjut dan menghasilkan malai. Tetapi tidak selamanya demikian karena pembentukkan anakan dipengaruhi oleh faktor lingkungan.

Menurut Tirtowirjono (1988), jumlah anakan produktif dikatagorikan menjadi 3 kelompok yaitu: sedikit (kurang dari 10 anakan produktif), sedang (10-15 anakan produktif), dan banyak (lebih dari 15 anakan produktif).

Menurut Cepy dan Wayan (2011), tinggi rendahnya pertumbuhan serta hasil 
tanaman dipengaruhi oleh 2 faktor yaitu internal yang meliputi sifat genetik atau turunan tanaman dan eksternal yaitu faktor lingkungan seperti iklim tanah dan faktor biotik. Perbedaan jumlah anakan masingmasing kultivar diduga karana pengaruh faktor-faktor tersebut. Hal tersebut sejalan dengan hasil penelitian dari Anhar et al. (2016), yang menyatakan bahwa jumlah anakan dan tinggi tanaman yang berbeda dikarenakan setiap varietas memiliki sifat gen yang berbeda-beda. Menurut Husana (2010), jumlah anakan akan maksimal apabila tanaman memiliki sifat genetik yang baik di tambah dengan keadaan lingkungan yang menguntungkan atau sesuai dengan pertumbuhan dan perkembangan tanaman.

\section{Berat Panen (gram/plot)}

Berdasarkan hasil analisis sidik ragam menunjukkan bahwa genotipe tidak berpengaruh nyata terhadap parameter berat panen. Rata-rata berat panen tanaman padi di uji dengan BNJ pada taraf 5\% dapat dilihat pada tabel 4 .

Tabel 4. Rerata berat panen perlakuan 12 genotipe padi lokal

\begin{tabular}{ll}
\hline Genotipe (P) & Rerata (gram) \\
\hline PL01 : Singgam Kuriak & 13,07 \\
PL02 : Pulut Solok & 9,52 \\
PL03 : Pulut Kari & 12,46 \\
PL04 : Pulut Benai & 11,02 \\
PL05 : Pulut Kuning & 12,76 \\
PL06 : Padi Adam & 8,95 \\
PL07 : Padi Putiah & 11,48 \\
PL08 : Lupo Ka Laki & 4,84 \\
PL09 : Padi Kuning & 12,53 \\
PL10 : Gondok/Pelita & 13,97 \\
PL11 : Saronda Kuning & 12,25 \\
PL12 : Katiok Putiah & 11,33 \\
\hline KK=16,0\% & \\
\hline
\end{tabular}

Berdasarkan tabel 4 menunjukkan bahwa perlakuan genotipe tanaman padi memberikan pengaruh yang tidak nyata terhadap parameter berat panen tanaman padi. Genotipe PL10 (Gondok/Pelita) memiliki rerata berat panen paling berat yaitu 1,25 ton/ha. Sedangkan jumlah rerata terendah terdapat dalam perlakuan PL08 (Lupo Ka Laki) yaitu 0,43 ton/ha. Walaupun perlakuan ini tidak memberikan pengaruh pengaruh yang nyata namun hasil terbaik terdapat pada PL10 yaitu 1,2 ton/ha.

Hal ini diduga oleh faktor lingkungan sehingga belum mampu menunjukkan respon pada jumlah anakan genotipe tanaman padi. Berat panen atau produksi tidak memberikan pengaruh yang nyata. Hal ini disebabkan oleh faktor genetik karena penggunaan varietas yang berbeda tidak menunjukkan perbedaan terhadap berat panen. Perbedaan dari jumlah gabah total per malai diduga disebabkan oleh pengaruh genetik dari masing-masing genotipe yang berbeda. Namun selain dari pengaruh genetik, faktor lingkunganpun mempengaruhi jumlah gabah total permalai. Jumin (2002), menyatakan bahwa sifat masing-masing genetik dan lingkungan tempat tumbuh dari varietas, akan mempengaruhi kepadatan butir tiap malai. Berat panen terhadap perlakuan 12 genotipe tanaman padi tidak memberikan pengaruh yang nyata. Hal ini dipengaruhi oleh beberapa faktor genetik dan lingkungan sehingga belum mampu memberikan pengaruh yang nyata. Hal ini sesuai dengan pernyataan Senewe dan Alfons (2011), perbedaan produksi total 
dapat disebabkan oleh perbedaan komposisi genetik dari masing-masing kultivar padi, sehingga responnya terhadap lingkungan juga berbeda. Selain genetik, faktor lingkungan juga berpengaruh pada produksi tanaman.

\section{KESIMPULAN}

Perlakuan 12 genotipe memberikan pengaruh yang nyata terhadap tinggi tanaman dan umur panen dengan perlakuan terbaik pada tinggi tanaman yaitu PL09 (Padi Kuning) dengan tinggi tanaman $140,94 \mathrm{~cm}$ dan umur panen pada genotipe PL11 (Saronda Kuning) yaitu 104 HST. Sedangkan genotipe yang tidak memberikan pengaruh yang nyata yaitu jumlah anakan dan berat panen. Parameter jumlah anakan tanaman padi terbanyak pada genotipe PL11 (Saronda Kuning) memiliki rerata jumlah anakan paling banyak yaitu 11,77 batang dan parameter berat panen tanaman padi terbanyak yaitu genotipe PL10 (Gondok/Pelita) memiliki rerata umur panen paling berat yaitu 13,97 gram/plot setara dengan 1,25 ton/ha.

\section{DAFTAR PUSTAKA}

Anhar. R, Ertita. H, Efendi. 2016. Pengaruh Dosis Pupuk Urea Terhadap Pertumbuhan dan Produksi Plasma Nutfah Padi Lokal Asal Aceh. Jurnal Kawista 1(1):30-36

Cepy dan W. Wangiyana. 2011. Pertumbuhan dan Hasil Tanaman Padi (Oryza sativa L.) di Media Vertisol dan Entisol Pada Berbagai Teknik Pengaturan Air dan Jenis Pupuk. Crop Agro. Vol 4 (2) : 4956.

Ezward C, Elfi I, Seprido dan Mashadi. 2017. Peningkatan Produktivitas Tanaman Padi melalui Teknik Budidaya dan Pupuk Kompos Jerami. Agrosains dan Teknologi Volume 2 Nomor 1, hlm 51-68

Ezward. C, Dadang. K dan Haris. S. 2019. Pengaruh pemberian berbagai dosis Limbah padat kelapa sawit (Sludge) terhadap pertumbuhan dan produksi padi dengan metode Jejar legowo 4 : 1. Jurnal Sain Agro Vol 4 Nomor 1 Fadjrin, MR, 2016 Komposisi Unsur Dalam Pupuk, (Online) (www.Chemistrik.com/2016/04Ko mposisiUnsurHaraDalamPupuk.ht $\underline{\mathrm{ml}})$

Husna dan Andrian. 2010. Pengaruh Penggunaan Jarak Tanam Terhadap Pertumbuhan Dan Produksi Padi Sawah (Oryza sativa L.) varietas IR 42 Dengan Metode SRI (System Of Rice Intensification). Skripsi Fakultas Pertanian Universitas Riau.

Indrawanis, Chairil dan Mashadi 2014. Pengkajian Varietas terhadap Pertumbuhan dan Produksi Padi sawah (Oryza sativa.L) Irigasi di Desa Petapahan Kec. Gunung Toar. Laporan Penelitian Dosen

Jumin, H. B. 2002. Agroekologi : Suatu Pendekatan Fisiologis. Rajawali Press. Jakarta. 179 hal.

Laila Nazirah dan B. Sengli J. Damanik. 2015. Growth and Yield of Three Upland Rice Varietes under Different Doses of Fertilization. J. Floratek 10 (1) :54-60

Martono B 2009. Keragaman Genetik, Heribilitas dan Korelasi Antar Karakter Kuantitatif Nilam (Pogostemon sp.) Hasil fusi Protoplas. Jurnal Littri.15(1) : 9-15

Masdar, M Karim, B Rusman, N. Hakim dan Helmi 2006. Tingkat Hasil Dan Komponen Hasil Sistem Intensifikasi Padi (SRI) Tanpa Pupuk Organik di Daerah Curah Hujan Tinggi. Jurnal Ilmu-Ilmu Pertanian Indonesia. Volume 8,No.2, 2006. Hal 126-131.

Purnamaningsi, Ragapadmi. 2006. Induksi Kalus dan Optimasi Regenerasi Empat Varietas Padi melalui Kultur In vitro. Balai Besar Penelitian dan Pengawasan Bioteknologi dan Sumber Daya Genetik Pertanian. Bogor. Jurnal AgroBiogen 2 (2) : 74-80. 
Purwasasmita. 2012. Padi SRI Organik Indonesia. Penebar Swadaya. Jakarta. 136-138 hal.

Rein E. Senewe dan Janes B. Alfons. 2011. Adaptation Study of Several New Varieties of Wet Land Rice Production Centers in West Seram Maluku Province. Jurnal Budidaya Pertanian, Vol. 7. No 2, 60-64

Sitompul, S. M dan Guritno, B. 1995.

Analisis Pertumbuhan Tanaman. UGM Press: Yogjakarta.
Syahri dan R.U. Somantri. 2013. Penggunaan varietas unggul tahan hama dan penyakit mendukung peningkatan produksi padi nasional. Jurnal Litbang Pertanian. 35 (1): 2536

Tirtowirjono, S. 1988. Identifikasi Varietas Unggul. Buletin Sang Hyang Seri 8. P. 32-34 